\title{
AL 14-LEA CONGRES DE PSIHOLOGIA MUNCII ŞI DEZVOLTAREA PERSOANELOR ŞI ORGANIZAȚIILOR AL COMUNITĂȚII DE PSIHOLOGIE FRANCOFONE
}

\author{
Cătălina Ciuce \\ Universitatea Babeş- Bolyai, Cluj Napoca
}

Anul acesta, în perioada $7 \quad-10$ iulie, Asociația Internațională de Psihologia Muncii de Limbă Franceză (L'association Internationale de Psychologie du Travail de Langue Française AIPTLF) a organizat cel de al 14-lea congres de psihologia muncii şi dezvoltarea persoanelor şi organizațiilor, la Hammamet, Tunisia.

Organizat pentru prima dată într-o țară africană, congresul din acest an vine cu un scop suplimentar prezentării ultimelor studii şi cercetări realizate la nivel internațional în acest domeniu susține preşedintele congresului, domnul Noureddine Krids. Acest scop se referă la dezvoltarea atât a psihologiei tunisiene în general, cât mai specific a domeniului psihologiei muncii, aflat deocamdată la început în această comunitate ştiințifică în care s-a introdus de curând studiul psihologiei muncii şi organizaționale.

În deschiderea congresului, Pierre Salengros de la Universitatea Liberă din Bruxelles, a realizat o trecere în revistă a practicilor actuale din domeniul psihologiei muncii, în cadrul unei prezentări intitulată sugestiv „Psihologia muncii şi dezvoltării: o chestiune de formă sau o chestiune de conținut?". Se atrage atenția în cadrul acestei discuții asupra problemelor generate de o separare a metodelor ştiințifice de conținuturile efective, mai ales în momentul în care metode de analiză specifice şi funcționale în cadrul anumitor comunități sunt aplicate fără 0 adaptare prealabilă în contexte diferite atât la nivel cultural, dar şi la nivel de stadiu de dezvoltare şi trebuințe specifice.

Participarea internațională importantă a constituit unul dintre punctele forte ale acestui congres şi a făcut oportună şi, totodată posibilă, trasarea unor direcții viitoare de dezvoltare la nivelul comunității ştiințifice fracofone. Ideile şi recomandările pentru acțiunile care trebuiesc implementate sunt următoarele: Crearea unor rețele europene pentru a realiza un schimb de informații, idei de cercetare, dar şi pentru a compara rezultate, sau a oferi instituțiilor sugestii mai valide şi cu un carcater mai general, în condițiile în care, Europa îşi stabileşte ca obiectiv, trasarea unui spațiu european de cercetare; crearea unei formațiuni de cercetători la nivel european care să favorizeze şi să stimuleze împărtăşirea şi schimburile continue de informații; stimularea colaborării dintre cercetare şi practică, pentru ca cele două să se dezvolte reciproc.

În ceea ce priveşte desfăşurarea efectivă a congresului, acesta a fost organizat într-o serie de sesiuni de prezentare a studiilor şi cercetărilor, tematica aleasă fiind extrem de variată şi incluzând probleme precum: sănătatea ocupațională şi problematica stresului profesional în general, identitate şi cultură organizațională, motivație angajament şi valori profesionale, interculturalitate şi diversitate în mediul organizațional, stiluri şi direcții de conducere, problematica accidentelor de muncă şi a riscurilor ocupaționale, ergonomie, selecție şi recrutare de personal etc.

Din păcate, în ciuda participării internaționale, nivelul ştiințific al congresului nu sa ridicat la standardele vizate. Fără a recurge la generalizări, nivelul lucrărilor nu a fost întotdeauna cel al unui congres internațional, ci dimpotrivă, s-au prezentat studii cu minusuri serioase, mai ales la nivel metodologic şi al statisticilor aplicate. Deşi pe lângă prezentarea în plen a lucrărilor a fost organizată şi o secțiune de postere, interesul participanților pentru aceasta a fost cît se poate de limitat, aspect valabil şi pentru participarea generală la secțiunile de lucrări. Este probabil uşor de explicat acest aspect în condițiile în care congresul s-a desfăşurat în incinta unui hotel superb pe marginea mării, iar bazarurile tunisiene situate în vechile medine, ale Hammametului reprezintă o concurență reală pentru manifestările ştințifice.

Deşi un eveniment extrem de plăcut din punct de vedere al interactiunii sociale, al posibilităților de colaborare viitoare pe plan internațional şi desfăşurat într-o locație extrem de fericit aleasă, se pot încă face îmbunătățiri importante la nivel ştiințific pentru ca acesta să devină un adevărat congres internațional al comunității francofone, la standarde de cea mai înaltă clasă, aşa cum ar merita. 